\title{
Influence of Entrepreneurial Orientation on Kenya's Manufacturing Firms Operating under East African Regional Integration
}

\author{
Samwel Otieno (Corresponding Author) \\ Jomo Kenyatta University of Agriculture and Technology, P.O. Box 62000-00200, \\ Nairobi, Kenya \\ School for Human Resource Development, Entrepreneurship and Procurement \\ Department
}

Tel: +254-722-248-376, +254-733-248-376 E-mail: samootieno2010@ gmail.com

Prof. Henry M. Bwisa

Jomo Kenyatta University of Agriculture and Technology, P.O. Box 62000-00200, Nairobi, Kenya

School for Human Resource Development, Entrepreneurship and Procurement

Department

Tel: +254-722-858-507 E-mail: bwihem@yahoo.com

Dr. John M. Kihoro

Jomo Kenyatta University of Agriculture and Technology, P.O. Box 62000-00200, Nairobi, Kenya

Faculty of Science, Statistics and Actuarial Science Department

Tel: +254-715-973-820 E-mail: kihoro_jm@yahoo.com

Accepted: December 01, 2012 Published: January 30, 2012

Doi:10.5296/ijld.v2i1.1326 URL: http://dx.doi.org/10.5296/ijld.v2i1.1326

\begin{abstract}
Entrepreneurial Orientation is a significant influencer of firm performance more so for manufacturing firms operating under globalization, internationalization and regional integration regimes. Regionalization is the coming together by nations as a means of attaining socio-economic and political goals by nations, which cannot be achieved in isolation.
\end{abstract}


Regionalization results in expanded markets, characterized by increased number of competition, and increased market size. This therefore, exerts greater pressure on manufacturing firms to regionalize; this is a challenge to firms accustomed to operating under a domestic market set-up.

To overcome the challenges associated with regionalization, eminent scholars in other parts of the world have recommended, that, manufacturing firms adopt Entrepreneurial Orientation as a solution to the challenges brought about by regionalization. It is on this basis that the study sought to determine the influence of entrepreneurial orientation on the performance of manufacturing firms in Kenya operating under the East African Community regional integration.

The study findings revealed that performance of Kenya's manufacturing firms operating under the East African Community regional integration, are significantly influenced by entrepreneurial orientation, in terms of Sales, Profits and Employment as measures of firm performance. The significance influence is more pronounced in terms of Sales for manufacturing firms which are integrated or operate within the regional integration. The study concluded that Kenya's manufacturing firms intent on enhancing their performance urgently need to adopt entrepreneurial orientation and recommends that further study be undertaken in other areas besides entrepreneurial orientation as an influencer of manufacturing firm performance.

Keywords: Entrepreneurship, Entrepreneurial Orientation, Competitiveness, Firm Performance, Regional Integration.

\section{Introduction}

Entrepreneurship is critical for social and economic development of many countries. Yet, most of the past research on entrepreneurship is devoted to the accomplishments of small businesses and new business ventures without much focus on its roles in regional and international context. Regional and International entrepreneurship deserves attention from researchers given the large number of Micro, Small and Medium Enterprises (MSMEs) and new ventures now going regional to exploit profits from regional markets. This is true in today's global business era. Apart from its contribution to development, entrepreneurship is considered important to the success of firms (Luo, 1999). This underscores the importance of undertaking a study on how entrepreneurship enables firms to achieve superior performance.

According to Knight (1997), the global trend is for firms operating under regional integration regimes, characterised by expanded markets, to embrace Entrepreneurial Orientation as an important competitive strategy for enhanced performance of manufacturing firms. Citing study findings on the experience of Canadian manufacturing firms operating under North American Free Trade Agreement (NAFTA) as a regional trading area, he avers that, manufacturing firms operating in countries which are members of regional integration regimes are directly influenced by entrepreneurial orientation. This influence is not only confined to firms 
operating within NAFTA, but to other regional integration areas, key characteristics of regional integration area are more similar, than differences that may be experienced.

Regional integration is the coming together of two or more states, normally through reciprocal preferential agreements, based on one or more successively integrating cooperation arrangement such as Preferential Trade Area (PTA), which accords preferential access to certain products from participating member countries. This is undertaken by reducing tariffs, but not abolishing them completely. It is the first stage of regional integration. The difference between a PTA and a Free trade area (FTA) may be blurred, as almost any PTA has a main goal of becoming a FTA in accordance with the General Agreement on Tariffs and Trade (GATT). Free Trade Area (FTA), is a form of Preferential Trade Area (PTA) without any tariffs on fellow members' goods, it is further recognized as an agreement in which member states charge lower tariffs to imports produced by fellow member countries than for non-members (Fondad, 2005).

After FTA, follows the Customs Union. This is a form of FTA which uses common tariffs on imports from non-members. A Custom Union further matures into a Common Market, which is characterized with free movement of factors of production, while Economic Community is a single-currency common market in which fiscal and monetary policies are unified. The ceding of political sovereignty in an economic community, leads to a federation or political union with common legislation and political structures.

There exist Pros and Cons of regional integration. The Pros of regional integration includes the ability to foster competition, subsidiarity, access to wider market, larger and diversified investment and production, socio-economic and political stability and bargaining power for the countries involved. It can be multi-dimensional to cover the movement of goods and services, capital and labour, socio-economic policy coordination and harmonization, infrastructure development, environmental management, and reforms in other public goods such as governance, peace, defence and security. However, the Cons of regional integration encompass perceived real gains or losses among member countries that may lead to disputes and a sense of loss of national sovereignty. For success, regional integration requires strong commitment in implementing the agreed arrangements, fair mechanisms to arbitrate disputes and equitable distribution of the gains and costs of regional integration.

In Africa, the East African Community (EAC) is one of the regional integration bodies which comprise of Kenya, Uganda, Tanzania, Rwanda and Burundi (EAC, 2010). Most of the characteristics of regional integration regimes also prevail within the EAC regional integration area. It has led to the expansion of market for manufacturing firms, and also a moderating influence on performance of manufacturing firms. Regional integration presents a challenge to firms accustomed to operating within the domestic market. The challenges are in form of increased number of competing firms, lower production and marketing costs, larger market and greater pressure on firms to regionalize (Jain, 1990; Czinkota and Ronkainen, 1995; Wiklund \& Shepherd, 2005). 


\subsection{Role of Entrepreneurial Orientation}

Firms which aspire to operate in a regional integration set-up, anticipate enhanced performance and success in their endeavours, this calls for them to urgently adopt Entrepreneurial Orientation (EO). EO is the strategy making practices that firms make to identify and launch ventures. It represents a frame of mind and a perspective about entrepreneurship that are reflected in a firm's on going processes and corporate culture (Lumpkin, 1996). Knight (1997) avers that firms which operate within a regional integration regime, which do not have the right frame of mind and perspective, encounter difficulties in enhancing their performance and competitiveness. Firms are therefore, encouraged to embrace entrepreneurial orientation to excel and overcome the challenges.

Despite the challenges encountered by firms operating under regional integration regimes, there exists a remedy in the form of adoption of entrepreneurial orientation, which is a key mitigating measure to the challenge. This study finding undertaken by Knight (1997); Wang (2008) and Adegbite (2007) in North America, Asia and Africa respectively confirm this. Entrepreneurship Orientation (EO) is an important in addressing the challenges encountered by manufacturing firms operating within a regional integration context. EO, is the processes, practices, and decision making activities that if embraced, influences performance of firms which operate both under the domestic market and under regional integration context EO therefore, is the firm's basic underlying strategy which greatly influences firm performance (Lumpkin \& Dess, 1996).

Schumpeter (1934) avers in his theory on innovation, that, an entrepreneurial firm is one which combines various input factors to generate value that exceeds the cost of input factors for profit. The theory is applicable to manufacturing firms in Kenya, which operate within the context of the East African Community (EAC). According to Morris \& Allen (1991), EO incorporates management proclivity for risk-taking, referred to as the degree the management is willing to make large and risky resource commitments, which have a reasonable chance of failure. Possession of a proactive competitive posture is the extent to which a firm anticipates and acts on future needs, seeks new opportunities which may or may not be related to the present line of operations, introduces new products and brands ahead of competition, and strategically eliminates operations which are in their mature or declining stages of life cycle (Knight (1997). Venkataraman (1989) avers that EO is the firm's ability to adopt innovative, proactive, and risk-seeking strategies to achieve performance objectives.

McClelland (1961) theory of high need for achievement is critical to a firm's strategy to attain market leadership by employing innovative marketing techniques. This theory is further supported by Kotler and Armstrong (1996) who together uphold the need for employing highly skilled sales force, and control of distribution channels. According to Bharadwaj and Varadarajan (1993), Quality leadership is an approach that is conducive to increased market share and profitability, while Cost leadership is characterized by tight control of overhead and variable costs, optimal use of production capacities, and pricing at or below competitive price 
levels. Morrison and Roth (1992) avers that, manufacturing leadership is reflected by a firm's innovative manufacturing processes, state-of-the-art plant and equipment, and emphasis on efficient production, which culminates in superior performance.

Porter (1990) refers to superior product quality as the perceived characteristic of products that meet or exceed customer expectations regarding features and performance. Increased competition brought about by regional trade regime affords end-users an opportunity to compare across a greater volume and variety of product brands from competing firms. Hence, firms are inclined to benchmark their quality standards against those of cross-regional competitors, leading to pressure on manufacturing firms to improve and thereby enhance their performance.

This study was undertaken within the context of establishing the influence of entrepreneurial orientation among manufacturing firms in Kenya, and the significance of the influence in their performance while operating under the moderating influence of the East African regional integration. Various research studies have confirmed that entrepreneurial orientation greatly influences performance of manufacturing firms in other parts of the world, this trend has been replicated globally, more so for manufacturing firms operating under regional integration context. Manufacturing firms in Kenya are bedevilled with challenges associated with doing business in an environment of increasing competition and regionalization, which, if mitigation measures are not urgently instituted, are likely to have a negative impact on their performance and competitiveness. It is in this respect that, manufacturing firms need to adopt entrepreneurial orientation if they desire to enhance their performance and competitiveness. The need to adopt EO becomes more urgent in view, that Kenya is a member of EAC regional integration regime which she adopted in the year 2000 (RoK, 2005; EAC, 2010).

According to KAM (2006), Kenya is ranked first in so far as having the most developed manufacturing sector among EAC member countries. However, despite Kenya being ranked first, there exists a challenge from neighbouring countries such as Uganda, Tanzania, Rwanda, and Burundi, which are venturing into the manufacturing sector, resulting in increased competition, lower production costs, and greater pressure for manufacturing firms to regionalize. This study was undertaken within the context of establishing the level of adoption and influence of Entrepreneurial Orientation as a means of overcoming the challenges, and how it influences performance of Kenya's manufacturing firms operating under the moderating influence of East African Community regional integration.

\section{Literature Review}

Entrepreneurial orientation theories comprise a summation of various bodies of knowledge which form the gist of entrepreneurship. The theories advanced are critical for a clear understanding of how entrepreneurial orientation influences firm performance for firms operating under a regional integration regime. The theories which form the bedrock of this study are anchored under entrepreneurial orientation. 


\subsection{Theory on Entrepreneurial Orientation (EO)}

Entrepreneurial Orientation (EO) refers to processes, practices, and decision-making activities of firms that lead to new entry and enhanced performance of manufacturing firms operating under a regional integration context (Lumpkin and Dess, 1996). According to Knight (1997), EO is the magic strategy which firms adopt to enter, maintain or augment their viability in situations of regional integration. It is associated with product innovativeness, process innovativeness, technological innovativeness, management proclivity for risk-seeking and pro-active competitive posture. The EO theory is, therefore, anchored on a firm's basic underlying orientations, processes, practices, and decision-making activities that are imperative to the firm's success (Knight, 1997).

Manufacturing firms need to develop certain capabilities to help them navigate successfully the prevailing scenario of regionalization. This led to the identification of entrepreneurial orientation as a key strategy, designed to support firms succeed in regional market place (Zahra and Garvis, 2000). An entrepreneurial firm is, one that engages in product-market innovation, undertakes somewhat risky ventures, and is first to come up with proactive innovations, beating competitors to the punch. Such characteristics are associated with improved firm performance in today's business environment, where product and business model life cycles are shortened, future profit streams from existing operations are uncertain, and entrepreneurs need to constantly seek out new opportunities (Wiklund \& Shepherd, 2005).

\subsubsection{Product Innovativeness}

Innovativeness is one of the most important characteristics of entrepreneurs. Concepts of creativity and innovativeness are mostly used together; however, they are not the same thing. The difference between them is embodied in the thinking of doing something and actually doing it. In this context, creativity is the spending of mental energy on new things, whereas innovativeness is doing and applying new things. Through innovativeness, new thoughts are used to produce new resources to satisfy needs. Emerging with change and improvement, innovativeness is closely related to mental processes, such as problem solving, constructive thinking, or invention which is the initiation of change. Product Innovation is, therefore, the practical application of new ideas in an effective manner and in conjunction with the objectives of a firm to come up with new products, methods or change (Kuratko, 1994).

Schumpeter (1934) avers that innovation is the search for creative, unusual or novel solutions to problems, which take the form of new products or processes being introduced in a firm. He further avers that innovation is the introduction of new ways to solve customers' problems that benefit both the customer and the firm. It involves initiation of processes through which entrepreneurs create, increase wealth by trying new ways and introducing radical changes in the products to eliminate wastages and inefficiencies, reduce cost of inputs, and increase profits (Lumpkin \& Dess, 2000). 
Product Innovativeness is viewed from: industry-level, which consist of technological, market discontinuity; firm-level, which consist of technical and marketing know-how newness, which are further considered as the macro (industry) and micro (firm) indicators of overall product innovativeness. The industry-level and firm-level innovativeness influences new customer to opt for a firm's products. Product innovativeness is further viewed from a firm and customer perspectives. The firm perspective includes, familiarity with technical and marketing environments; and fit with technical and marketing resources. The customer perspective consists of, product attributes, adoption risk, and requirements for behavioural change. Product innovativeness is used to describe a firm's fitness or characteristics as a function of the extent to which an existing firm's resources and capabilities are used to develop the marketing and technical aspects necessary for new product development (Covin and Slevin, 1989). Knight (1997) avers that, product innovativeness is the degree to which a product is superior to that of competing products, product innovation occurs with the aim of making a competitive product, this advantage may stem from the innovativeness of a product.

\subsubsection{Process Innovativeness}

According to Venkataraman (1989) process innovation involves introduction of new processes, products and services to capitalize on market opportunities as an element of market pro-activeness. It is considered as a firm's tendency to engage in and support new ideas, novelty, experimentation, and creative processes that are likely to result in new products and services being introduced in the market (Wang, 2008).

Process innovativeness is considered as an organization's capabilities to marshal, integrate, and leverage organizational resources to improve or create new processes. According to Mosey (2005), existing studies focusing on new product development suggest that, product innovation activities are the cornerstone of better-performing companies, and those with aggressive growth ambitions. Mosey (2005) further posits that, manufacturing firms which repeatedly introduce innovative new products, end up opening up new market niches, which is essential to their survival. This is achieved through modern apprenticeships, student placement and school visits, which is a trait of an innovative manufacturing firm in general (Mosey, 2005). According to Luo (1999), studies have demonstrated that manufacturing firms operating under the moderating influence of regional integration were better able to innovate than those not operating under the moderating influence of regional integration, which is achieved mostly through clusters and networking.

According to Knight (1997) process innovativeness, refers to the creative or unique solutions for the threats that a manufacturing firm encounters. Through process innovativeness, manufacturing firms gain competitive superiority by producing very ordinary and standard products in very high innovative processes, which provide the advantage of low cost, rapid production, faster distribution, more quality and better customer services. 


\section{Macrothink Institute ${ }^{T M}$

\subsubsection{Technological Innovativeness}

Technological Innovation is a dynamic network of agents interacting in a specific economic or industrial area, under an institutional infrastructure involved in the generation, diffusion, and utilization of technology in a sector (Covin \& Slevin, 1991). It is concerned with elevating a manufacturing firm to have competitive advantage over competitors by stimulating dynamic knowledge flows to create new business opportunities, and adopt modern techniques of operations ahead of competitors (Pearce \& Robinson, 2007). The search for creative, unusual or novel solutions to the manufacturing firm's operations by introducing technological innovativeness is what distinguishes successful entrepreneurs from others (Adegbite, et al, 2006).

According to Dess et al. (1997), technology Innovativeness focuses primarily on product and process development, engineering, research and development, technical expertise and industry knowledge. Innovation is commonly viewed as creativity, which is considered the creation of new ideas and knowledge. However, it is recognized that new ideas do not add value or contribute to entrepreneurship or businesses until people un-shelf the new ideas from the laboratory, implement them, and generate values to customers. Mosey (2005) avers that, a good new idea means little except risk, without excellence in execution.

Technology innovativeness is a measure of the degree of radically adopted innovations, relative advantage of adopted innovations and number of adopted innovations. It is also measured in terms of number of innovation adoptions, time of innovation adoptions and consistency of innovation adoptions. Therefore, it is clear that innovative firms or organizations are those that exhibit innovative behaviour which is consistent over time.

\subsubsection{Management Proclivity for Risk-Taking}

Firms would like to become entrepreneurial. In order to do this requires a high level of drive and energy; enough self-confidence to take carefully calculated, moderate risks (Knight, 1997). According to Zahra (2000), success of firm performance often equates to the level of risk-taking engaged. The word risk commonly stirs negative connotations and sends thoughts of dwelling on potential failure, even disaster. However, the more we become complacent and comfortable in our lives, the more we tend to avoid risk. However, for the rest of enterprising manufacturing firms wanting to enhance their performance, risk-taking is a necessity for growth and survival of enterprises. In taking risks, there is the potential for significant returns on performance of manufacturing firms, beyond that, there is a stimulation of creativity, innovation, increase in competence and improved performance (Miller and Friesen, 1984).

Risk-taking is the willingness to commit significant resources to opportunities having a reasonable chance of costly failure. These risks are typically manageable and calculated (Covin \& Slevin, 1991). A high propensity to take calculated risks is considered important to the firm's management; hence, a successful entrepreneur's attribute to their success in business is dependent on their ability to take calculated chance or risk. The more risk-averse a firm's management is, the more they do not enhance their performance, while the less 
risk-averse a manufacturing firm's management is, the better as they become entrepreneurs and enhance their performance. Schumpeter (1934) avers that, entrepreneurs only take calculated risks, as their propensity for risk-taking is tempered by sound business judgment, precluding risk-taking in the extreme. They attempt to minimize risks by remaining focused on the opportunity and enhanced performance.

Firms which are risk tolerant and innovative, have characteristics which eliminate traditional authoritarian, hierarchical structures that inhibit their performance (Ireland \& Sexton, 2001). A risk-tolerant and innovative orientation means that, firm managers encourage new ways of thinking, tolerate mistakes, and reward new ideas that contribute to innovation and enhanced business performance. They promote a sense of open-mindedness, since individuals are neither constrained within a frame of thinking nor punished for making mistakes. The breakdown of traditional authoritarian and hierarchical structures also brings about firm's communications that facilitate the development of a shared vision (Miller \& Friesen, 1983).

Entrepreneurs with innovativeness, risk-taking traits, focus more on opportunities which play a critical role in the change and development of manufacturing firms. Therefore, entrepreneurs with these qualities are important to manufacturing firms. The entrepreneurs can take calculated risks and produce creative and innovative solutions to problems, whereas their manufacturing firms can become change oriented and have room for development. However, it is recognized that, enhanced firm performance cannot be achieved without willingness, effort, and courage of the entrepreneurs. It is critical for manufacturing firms operating under regional integration context to adopt calculated risk characteristics in order to enhance their manufacturing firm performance (Knight, 1997).

\subsubsection{Pro-active Competitive Posture}

Pro-active competitive posture refers to how a firm anticipates and acts on future needs, by seeking new opportunities which may or may not be related to the present line of operations. It is considered as the introduction of new products and brands ahead of competition, by eliminating operations which are in their mature or declining stages of life cycle (Venkataraman, 1989). Adegbite, et.al (2007) avers that, pro-active competitive posture is the implementation and bringing an entrepreneurial concept to fruition, involves perseverance, adaptability and a willingness to assume responsibility for failure. It ensures success while coping with competitive forces of threats of new entrants, threats of substitute products, bargaining power of consumers, rivalry among competitors, and bargaining power of suppliers.

Pro-active competitive posture is the strategic advantage one manufacturing firm has over its rival firms within its competitive industry. Achieving competitive posture strengthens the manufacturing firm and positions a firm better within the business environment. Competitive advantage occurs when an organization acquires or develops an attribute or combination of attributes that allows it to outperform its competitors. These attributes include access to inputs 
used in the manufacturing process, access to markets for the firm's products and services, access to highly trained and skilled personnel human resources or new technologies such as robotics and information technology, which are important to manufacturing firms operating under regional integration (Knight, 1997).

\section{Main Objective}

The main objective of the study was to establish the influence of Entrepreneurial Orientation on performance of Kenya's manufacturing firms operating under the moderating influence of EAC regional integration.

\subsection{Specific Objectives}

1. To establish the level of adoption of Entrepreneurial Orientation (EO) by Kenya's manufacturing firms operating under the moderating influence of East African Community (EAC) regional integration.

2. To determine the significance of East African Community (EAC) regional integration in moderating EO on performance of Kenya's manufacturing firms.

3. To establish the significance of adoption of Entrepreneurial Orientation on performance of Kenya's manufacturing firms operating under the moderating influence of EAC regional integration.

\subsection{Conceptual Framework}

The study's conceptual framework was anchored on entrepreneurial orientation as an independent variable, EAC regional integration as a moderating variable and Firm Performance as the dependent variable as depicted in fig. 1 below.

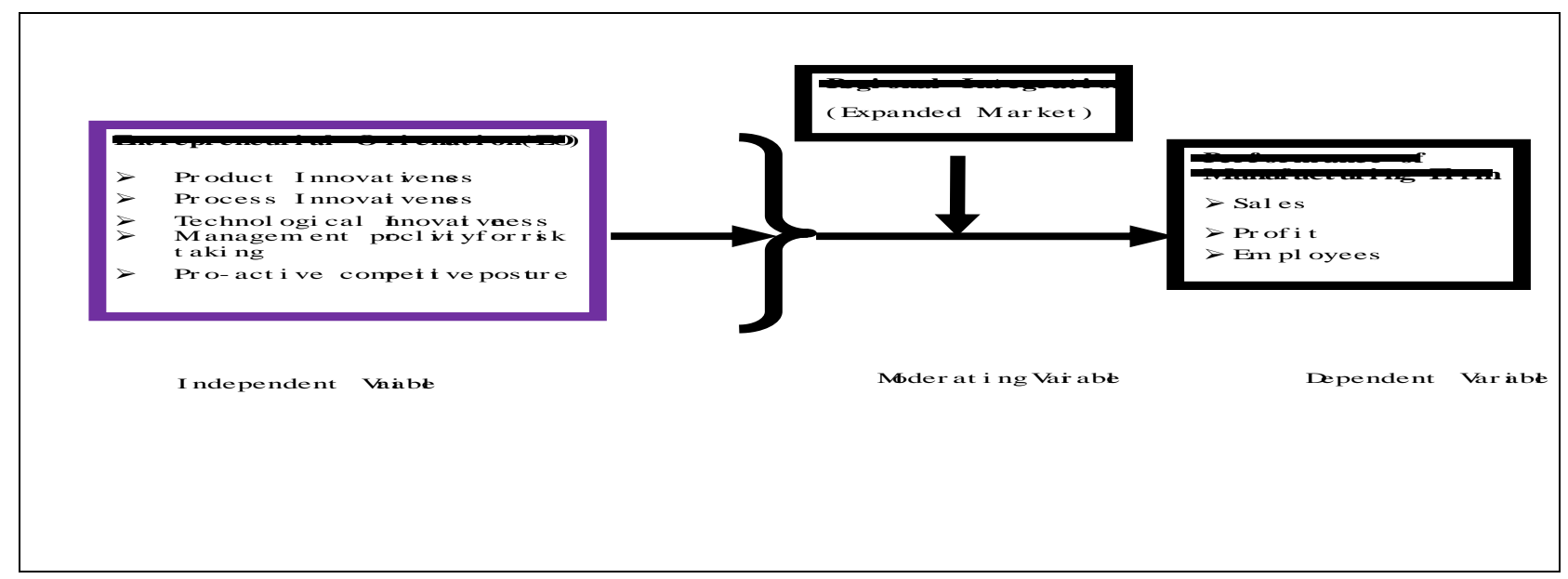

Fig 1. Influence of EO on Firm Performance

Source: Conceptual Model adapted from Knight (1997) 
According to Fig. 1 above, the conceptual framework provides a foundation upon which deepening of understanding on how Entrepreneurial Orientation influences performance of manufacturing firms under the moderating influence of regional integration was undertaken.

\section{4. $\quad$ Research Questions}

1. What is the level of adoption of Entrepreneurial Orientation (EO) by Kenya's manufacturing firms operating under the moderating influence of East African Community $(E A C)$ regional integration?

2. What is the significance of the East African Community (EAC) regional integration as a moderator of Entrepreneurial Orientation and Strategy on performance of Kenya's manufacturing firms?

3. Is there a significant relationship between performance of manufacturing firms in Kenya and adoption of Entrepreneurial Orientation and Strategy for manufacturing firms operating under the moderating influence of EAC regional integration?

\section{Research Methodology}

The study adopted both quantitative and qualitative exploratory research design. Quantitative research design focused on the designs, techniques and measures that produced discreet numerical or quantifiable data (Kothari, 2007). Further, quantitative approach was strongly linked to answering research questions, which were directly linked to specific objectives of the study.

Qualitative approaches were useful in enhancing understanding of social constructs and meanings as alluded to by Kothari, (2007); and Saunders et al, (2003), in which qualitative approach seeks to explain constructs and phenomena that are not statistically significant or quantitative in nature and is a good tool for analysing social scenarios that are characterized by qualitative factors.

Both approaches were used to determine the level of influence of Entrepreneurial Orientation on the performance of manufacturing firms in Kenya operating under the moderating influence of EAC regional integration. The first step involved determining the level of adoption of the entrepreneurial orientation by the manufacturing firms in Kenya, followed by ranking (considered as weights) of the different aspects of EO in terms of perceived influence by the respondents. Finally, an analysis of the collected data was undertaken to determine the findings on the level of influence and significance of Entrepreneurial Orientation, on manufacturing firms in Kenya operating under the moderating influence of the East African Community (EAC) regional integration.

The research study was undertaken on manufacturing firms in Nairobi and surrounding area, where 525 of the 698 of the manufacturing firms registered with the Kenya Association of 
Manufacturers (KAM) are located. Further, 5 sub-sectors were identified based on their high export potential and greater potential to enhance performance within the EAC regional integration area. The subsector contributed $69 \%$ of the total percentage export earnings in the manufacturing export earnings in the year 2004, and a percentage export earnings of $8 \%$ and above in 2004 (KAM, 2006). The sub-sectors were Food, Beverages and Tobacco; Metal and Allied; Building, Construction and Mining; Chemical and Allied; and Leather Products and Footwear. The sample for the study was identified by use of Purposive Sampling and Simple Random Sampling techniques. A sample size of 138 was recommended for the study which was based on sample size determination formula, however, 150 manufacturing firms responded to the study after 180 questionnaires were sent out.

\section{Research Findings and Discussions}

\subsection{Empirical Research Findings on the adoption level of EO}

The table 1 below is a presentation of the findings on the level of adoption of EO.

Table 1. Adoption level of Entrepreneurial Orientation

\begin{tabular}{|c|c|c|c|c|c|c|c|c|c|c|c|c|}
\hline \multirow[b]{2}{*}{ Strategy } & \multicolumn{2}{|l|}{ Never } & \multicolumn{2}{|l|}{ Rarely } & \multicolumn{2}{|c|}{ Sometimes } & \multicolumn{2}{|c|}{ Usually } & \multicolumn{2}{|c|}{$\begin{array}{l}\text { Always to the } \\
\text { max level }\end{array}$} & \multirow{2}{*}{$\begin{array}{l}\text { Total } \\
\text { Count }\end{array}$} & \multirow{2}{*}{$\begin{array}{l}\text { Total } \\
\%\end{array}$} \\
\hline & Count & $\%$ & Count & $\%$ & Count & $\%$ & Count & $\%$ & Count & $\%$ & & \\
\hline $\begin{array}{l}\text { Product } \\
\text { innovation }\end{array}$ & 7 & 4.7 & 4 & 2.7 & 17 & 11.5 & 36 & 24.3 & 84 & 56.8 & 148 & 100 \\
\hline $\begin{array}{l}\text { Process } \\
\text { Innovation }\end{array}$ & 4 & 2.7 & 12 & 8.1 & 7 & 4.7 & 55 & 37.2 & 70 & 47.3 & 148 & 100 \\
\hline $\begin{array}{l}\text { Technological } \\
\text { innovativeness }\end{array}$ & 3 & 2 & 8 & 5.4 & 22 & 15 & 52 & 35.4 & 62 & 42.2 & 147 & 100 \\
\hline $\begin{array}{l}\text { Management } \\
\text { risk taking }\end{array}$ & 8 & 5.5 & 28 & 19 & 33 & 22.6 & 46 & 31.5 & 31 & 21.2 & 146 & 100 \\
\hline $\begin{array}{l}\text { Competition } \\
\text { strategy }\end{array}$ & 20 & 13.6 & 7 & 4.8 & 33 & 22.4 & 43 & 29.3 & 44 & 29.9 & 147 & 100 \\
\hline Total & 42 & 28.5 & 59 & 40 & 112 & 76.2 & 232 & 157.7 & 291 & 197.4 & 736 & $\mathbf{5 0 0}$ \\
\hline $100 \%$ & & 5.7 & & 8 & & 15.24 & & 31.54 & & 39.48 & & 100 \\
\hline
\end{tabular}

Source: Author

From the result findings presented in table 1 above, it was observed that the adoption level of Entrepreneurial Orientation (EO) by manufacturing firms in Kenya, based on a scale of Never, Rarely, Sometimes, Usually and Always to the Maximum level. The findings reveal that $71.02 \%$ of all respondents indicated that they had adopted EO in their manufacturing 
firms, while $13.7 \%$ have rarely or never adopted EO in their manufacturing firms, with $15.24 \%$ of the respondents adopting EO sometimes. The findings demonstrate that a majority of manufacturing firms under study had adopted EO in their manufacturing firms, thereby confirming the perceived important role EO plays in enhancing manufacturing firm's competitiveness while operating under a regional integration context. The study findings also reveal that $84.5 \%$ of the respondents had adopted Process Innovation usually and always to the maximum. This is the highest adopted strategy within EO as the findings indicate. The study findings further revealed that a majority of respondents constituting $56.8 \%$ adopted Product Innovation always to the maximum level, while Management risk taking at $21.2 \%$ is the least always adopted strategy to the maximum level.

This, therefore, confirms that product innovation is greatly valued by Kenya's manufacturing firms as the best strategy for them to become or remain competitive among competitors within the East African regional integration. The important role Product innovation plays in enhancing manufacturing firm competitiveness within a regional integration regime is confirmed by Wang, 2008, who avers that Product Innovation involves introduction of new products and services to capitalize on market opportunities as an element of market pro-activeness, and firm's tendency to engage in and support new ideas, novelty, experimentation, and creativity that results in new products and services.

The study further sought to find out how Kenya's manufacturing firms perceived the influence of different strategies of EO by ranking them. The ranking of the different strategies within the EO was to enable an in-depth understanding of whether the perceived ranking of the different strategies was consistent with the perceived level of adoption of EO. This aspect of analysis was confined to manufacturing firms which were directly involved in the EAC regional integration ( $\mathrm{RI}=$ Yes) as presented in table 2 below:-

Table 2 Adoption and Ranking of Entrepreneurial Orientation (RI=Yes)

Adoption of EO Ranking of EO

Std.

Std.

\begin{tabular}{lcccccccccc} 
Strategy & $\mathbf{N}$ & Min & Max & Mean & Deviation & Rank & Min & Max & Mean & Deviation \\
\hline $\begin{array}{l}\text { Product } \\
\text { innovation }\end{array}$ & 108 & 1 & 5 & $\mathbf{4 . 3 1}$ & $\mathbf{1 . 0 6 3}$ & 1 & 1 & 5 & $\mathbf{4}$ & $\mathbf{1 . 2 2 3}$ \\
$\begin{array}{l}\text { Process } \\
\text { Innovation }\end{array}$ & 108 & 1 & 5 & 4.3 & 0.92 & 2 & 1 & 5 & 3.82 & 1.053 \\
$\begin{array}{l}\text { Technological } \\
\text { innovativeness }\end{array}$ & 108 & 1 & 5 & 4.24 & 0.91 & 3 & 1 & 5 & 3.4 & 1.115 \\
$\begin{array}{l}\text { Management } \\
\text { risk taking }\end{array}$ & 108 & 1 & 5 & $\mathbf{3 . 5 1}$ & $\mathbf{1 . 1 2 3}$ & 4 & 1 & 5 & $\mathbf{1 . 9 9}$ & $\mathbf{1 . 1 4 5}$ \\
$\begin{array}{l}\text { Competition } \\
\text { strategy }\end{array}$ & 108 & 1 & 5 & 3.73 & 1.233 & 5 & 1 & 5 & 2 & 1.032 \\
\hline
\end{tabular}


a. $\mathbf{R I}=$ Yes

Source: Author

Table 2 above presents the findings of the perceived level of adoption of EO by respondents and their ranking of the various EO strategies to confirm or disagree with their perceived choice of EO strategies which is most adopted by Kenya's manufacturing firms operating within the EAC regional integration. From findings presented in table 2 above, it is revealed that a majority of respondents indicated that Product Innovation is the most adopted strategy of EO with a Mean value of 4.31 and Standard Deviation value of 1.063, while Management Risk Taking is perceived to be the least adopted strategy with a Mean Value of 3.51 and Standard Deviation of 1.123. The findings also reveal that respondents ranked Product Innovation as the most perceived adopted EO strategy with a Mean value of 4.0 and Standard Deviation of 1.1223 , while the least ranked strategy was Management Risk Taking with a Mean value of 1.99 and Standard Deviation of 1.145. Therefore, the perceived level of adoption of the different strategies is consistent with the rankings of the different strategies of EO by the respondents.

Table 3. Adoption of EO for Firms where RI=Yes and RI=No

\begin{tabular}{|c|c|c|c|c|c|c|c|c|c|c|}
\hline Strategy & $\mathbf{N}$ & Min & $\begin{array}{l}\text { RI = } \\
\text { Yes to } \\
\text { Max }\end{array}$ & Mean & $\begin{array}{l}\text { Std. } \\
\text { Deviation }\end{array}$ & $\mathbf{N}$ & Min & $\begin{array}{l}\text { RI = } \\
\text { No to } \\
\text { Max }\end{array}$ & Mean & $\begin{array}{l}\text { Std. } \\
\text { Deviation }\end{array}$ \\
\hline $\begin{array}{l}\text { Product } \\
\text { innovation }\end{array}$ & 108 & 1 & 5 & 4.31 & 1.063 & 35 & 1 & 5 & 4.11 & 1.105 \\
\hline $\begin{array}{l}\text { Process } \\
\text { Innovation }\end{array}$ & 108 & 1 & 5 & 4.3 & 0.92 & 35 & 1 & 5 & 3.71 & 1.25 \\
\hline $\begin{array}{l}\text { Technological } \\
\text { innovativeness }\end{array}$ & 108 & 1 & 5 & 4.24 & 0.91 & 35 & 1 & 5 & 3.74 & 1.039 \\
\hline $\begin{array}{l}\text { Management } \\
\text { risk taking }\end{array}$ & 108 & 1 & 5 & 3.51 & 1.123 & 35 & 1 & 5 & 3.17 & 1.361 \\
\hline $\begin{array}{l}\text { Competition } \\
\text { strategy }\end{array}$ & 108 & 1 & 5 & 3.73 & 1.233 & 35 & 1 & 5 & 3.03 & 1.543 \\
\hline a. $R I=$ Yes & & & \multicolumn{8}{|c|}{ a. $R I=$ No } \\
\hline
\end{tabular}

Source: Author

The findings in table 3 above reveals that Kenya's manufacturing firms which are integrated or involved in the EAC regional integration trade ( $\mathrm{RI}=$ Yes) numbering 108 perceive adoption of Product Innovation as the most influential strategy among the EO strategies with a Mean level of 4.31 and Standard Deviation of 1.063, while they perceive adoption of Management Risk Taking as of minimal influence at Mean level of 3.51 and Standard Deviation of 1.123. However, firms which are not involved in EAC regional integration $(\mathrm{RI}=\mathrm{No})$ trade numbering 
35 also perceive adoption of Product Innovation as important for manufacturing firms, with a Mean level of 4.11 and Standard Deviation of 1.105. This Mean level of 4.11 is much lower than those involved in regional trade, which has a Mean level of 4.31. The findings were based upon the understanding that East Africa Community (EAC) is a regional integration area and acts as a moderating variable under the study, further, the measures were under a scale of minimum 1 to a maximum scale of 5 as depicted in the table above.

By using stepwise regression for a single variable to analyse Entrepreneurial Orientation (EO) on performance of Manufacturing Firms in terms of Sales (Ys) and further application of Analysis of Variance (ANOVA) $F$-test yielded the result as presented in table 4 below:

Table 4. Stepwise regression of EO on $\left(Y_{s}\right)$

ANOVA

\begin{tabular}{|c|c|c|c|c|c|c|c|}
\hline \multicolumn{3}{|c|}{$\begin{array}{l}\text { Regional } \\
\text { Integration Model }\end{array}$} & \multirow{2}{*}{$\begin{array}{l}\begin{array}{l}\text { Sum } \\
\text { Squares }\end{array} \\
1930.688\end{array}$} & \multicolumn{4}{|c|}{ of } \\
\hline \multirow[t]{3}{*}{ No } & 1 & Regression & & 1 & 1930.688 & .783 & $.382^{\mathrm{a}}$ \\
\hline & & Residual & 91229.264 & 37 & 2465.656 & & \\
\hline & & Total & 93159.952 & 38 & & & \\
\hline \multirow[t]{3}{*}{ Yes } & 1 & Regression & 13504.167 & 1 & 13504.167 & 5.744 & $.018^{a}$ \\
\hline & & Residual & 242160.924 & 103 & 2351.077 & & \\
\hline & & Total & 255665.091 & 104 & & & \\
\hline
\end{tabular}

a. Predictors: (Constant), EO

b. Dependent Variable: Ys

Source: Author

From table 4 above, it is noted that when Entrepreneurial Orientation (EO) was used as a predictor on dependent variable $\left(Y_{s}\right)$, and a comparison made between manufacturing firms which were active participants in the regional integration or integrated (RI=Yes) compared to those manufacturing firms which were not active participants in the regional integration or not integrated $(\mathrm{RI}=\mathrm{No})$, the result shows that manufacturing firms which were integrated $(\mathrm{RI}=\mathrm{Yes})$ were significantly influenced by regional integration at the level of $r=5.744, \quad p$-value $=0.018$ which is less than 0.05 level of significance. Hence, firm performance measured in terms of $\left(Y_{s}\right)$ is greatly influenced by manufacturing firms which adopted Entrepreneurial Orientation (EO) and operating under regional integration. On the other hand, the results reveal that firms which are not participants in regional integration ( $\mathrm{RI}=\mathrm{No}$ ) have less influence on the firms performance at the level of $\mathrm{r}=0.783$, $\mathrm{p}$-value $=0.382$ which is not significant at 0.05 level of significance.

\section{Conclusion}


The conclusions presented are drawn from the study findings and summary to the objectives of the study as here below:-

\subsection{Level of adoption of Entrepreneurial Orientation (EO)}

Arising from the study findings, it is confirmed that there exists a very high level of adoption of Entrepreneurial Orientation (EO) among Kenya's manufacturing firms operating under the moderating influence of East Africa Community (EAC) regional integration. The level of adoption of EO among Kenya's manufacturing firms is at $71.02 \%$. Among the different strategies comprising of EO, Product Innovation was the highest perceived strategy adopted and ranked strategy by Kenya's manufacturing firms operating under EAC regional integration. It is, therefore, important that Kenya's manufacturing firms which operate or intend to operate within the EAC regional integration to adopt EO and more particularly if they want to enhance the performance of their manufacturing firms in terms of Sales (Ys). This also confirms the findings of studies undertaken by Knight, 1997; Wang, 2008 that EO has a positive correlation between entrepreneurship and firm performance under regional integration context, as is the case with Kenya's manufacturing firms operating under the moderating influence of EAC regional integration.

\subsection{Significance of EAC regional integration}

Regional integration has an important influence in the performance of manufacturing firms within the confines of the region. This influence is not confined to regional integration regimes in other parts of the world, but also to the East African Community (EAC) as a regional integration regime. EAC regional integration regime influences performance of Kenya's manufacturing firms greatly in terms $\operatorname{Sales}\left(Y_{s}\right)$. EAC regional integration has provided a large market in terms of the increased population of consumers in the other countries, namely Burundi, Rwanda, Uganda and Tanzania besides Kenya, and therefore, its moderating influence in providing expanded markets is more reflected in the performance of Kenya's manufacturing firms in terms of Sales, Profit and Employment respectively. For those manufacturing firms in Kenya which would like to enhance their performance, it is important to operate under the EAC regional integration regime to reap the benefits and, therefore, experience the significant influence of EAC regional integration regime.

\subsection{Significance of adoption of EO on firm Performance}

From the study findings and summary, it is conclusive that performance of Kenya's manufacturing firms is significantly influenced by the adoption of EO for Kenya's manufacturing firms which operate under the moderating influence of EAC regional integration. The significance of adopting entrepreneurial orientation on performance of manufacturing firms is very strong when performance of manufacturing firms is measured in terms of $\operatorname{Sales}\left(Y_{s}\right)$, followed by $\operatorname{Profit}\left(Y_{p}\right)$, and less significant when measured in terms of 
Employment $\left(Y_{e}\right)$. It is, therefore, important for Kenya's manufacturing firms desirous of enhancing their performance under the moderating influence of EAC regional integration to adopt entrepreneurial orientation.

\section{Acknowledgement}

I wish to acknowledge the financial support received from the concluded Kenya Trade and Poverty Programme (KTTP) and the on-going Assistance to Micro and Small Enterprises Programme (ASMEP) under the Ministry of Trade to pursue this study. I further wish to acknowledge the enabling work environment availed by Eng. Abdulrazak A. Ali, The Permanent Secretary, Ministry of Trade, Mrs. Joyce A. Ogundo, The Director of Internal Trade and my colleagues at the ASMEP and the entire Department to pursue this study.

I wish to specially thank my supervisors, Prof. Henry Bwisa and Dr. John Kihoro, for their professionalism and patience in guiding me through the study, their high calibre of professional excellence and good team work. Without your invaluable professional guidance, this study would not have come to fruition. I am also grateful to my lecturers at the School of Human Resource Development (SHRD) of Jomo Kenyatta University of Agriculture and Technology (JKUAT) for their guidance and positive criticism.

Special thanks to my colleague Mrs. Jane Gathenya, for the invaluable discussions and encouragement. It is through these discussions that made completion of this study possible. This acknowledgment would not be complete without a mention of respondents in this study, the entrepreneurs in the manufacturing sector and my Research Assistants. To all mentioned by name and those not mentioned. I am greatly humbled by your selfless support. Thank you.

\section{References}

Adegbite, S. A. \& Abereijo, I.O. (2006). Entrepreneurial Orientation of Small-Scale Enterprise Operators in Nigeria. A Journal of Human Resource and Entrepreneurship Development, Vol.2 No.1 .January, 49-58.

Adegbite, S. A. \& Abereijo, I.O. (2007). Evaluation of the Impact of Entrepreneurial Characteristics on the Performance of Small Scale Manufacturing Industries in Nigeria, Journal of Asia Entrepreneurship and Sustainability, available at http://www.asiaentrepreneurshipjournal.com.

Bharadwaj, S.G. \& Varadarajan, P.R. (1993). Sustainable Competitive Advantage in Service Industries: A Conceptual Model and Research Propositions. The Journal of Marketing American Marketing Association.

Covin, J. G. \& Slevin, D.P. (1989). Strategic Management of Small Firms in Hostile and Benign Environment. Strategic Management Journal. 10: 75-87. 
Covin, J. G. \& Slevin, D.P. (1991). A Conceptual Framework of Entrepreneurship as a Firm Behaviour. Entrepreneurship Theory and Practice, 14(1) 7-26.

Covin, J. G. \& Slevin, D. P. (2006). Strategic Process Effects on the Entrepreneurial Orientation-Sales Growth Rate Relationship. Entrepreneurship Theory and Practice, 30 (1), 57-81.

Czinkota, M. \& Ronkainen, I. (1995). International Marketing. $4^{\text {th }}$ ed. Fort Worth, TX: The Dryden Press.

Dess, G.G., Lumpkin, G. T. \& Covin, J. G. (1997). Entrepreneurial Strategy Making and Firm Performance. Tests of Contingency and Configurational Models. Strategic Management Journal. 18(9): 677-695.

East African Community (EAC). (2010). East African Community, [online] available: http://www.eac.int/ . (Oct 14, 2011).

Fondad, (2005). Africa in the World Economy. The National, Regional and International Challenges, [online] available: http://www.fondad.org. (Oct 18, 2011).

Ireland, R.D., Hill, M.A., Camp, S.M., \& Sexton, D.L. (2001). Integrating Entrepreneurship and Strategic Management Actions to Create Firm Wealth. Academy of Management Executive, 15(1), 49-63.

Jain, S. (1990). International Marketing Management. $3^{\text {rd }}$ ed., Boston: PWS-Kent Publishing co.

Kenya Association of Manufacturers (KAM). (2006). A Survey of Kenya's Manufacturing Sector. Nairobi: Kenya Association of Manufacturers.

Kenya Association of Manufacturers (KAM). (2010). Kenya Association of Manufacturers Directory 2009/2010. Nairobi: Kenya Association of Manufacturers.

Knight, G. A. (1997). Firm Orientation and Strategy under Regional Market Integration: A Study of Canadian Firms. John Wiley \& Sons, Inc.

Kothari, C. R. (2007). Research Methodology - Methods and Techniques. New Delhi, India: New Age International Publishers.

Kotler, P. \& Armstrong, G. (1996). Principles of Marketing. USA. Englewood Cliffs, NJ: Prentice-Hall, $7^{\text {th }}$ Edition. 
Kritzinger van Niekerk, L. (2010). Regional Integration: Concepts, Advantages, Disadvantages and Lessons of Experience. World Bank Country Office. SA.

Kuratko, D.F. \& Welsch, H. P. (1994). Entrepreneurial Strategy Text and Cases. Fort Worth, TX: Dryden Press.

Lumpkin, G.T. \& Dess, G. G. (1996). Clarifying the Entrepreneurial Orientation Construct and Linking it to Performance. Academy of Management Review, 21(1), 135-172.

Lumpkin, G.T. \& Dess, G. G. (2000). Enhancing Entrepreneurial Orientation Research: Operationalizing and Measuring a Key Strategic Decision Making Process. Journal of Management, 7, 83-104.

Luo, Y. (1999).Environment-Strategy-Performance Relations in Small Businesses in China: Case of Township and Village Enterprise in Southern China. Journal of Small Business Management.37 (1):37-51.

Lyon, D., Lumpkin, G.T. \& Dess, G.G. (2000). Enhancing Entrepreneurial Orientation Research. Operationalizing and Measuring Key Strategic Decision Making Process. Journal of Management Studies. 26(5): 1055-1085.

McClelland, D. (1961). The Achieving Society. Free Press Paperback. MacMillan Co.

Miller, D. \& Friesen, P.H. (1983). Strategy-making and environment: The third link. Strategic Management Journal, 4(3), 221-235.

Miller, J.G. \& Roth, A.V. (1994). A Taxonomy of Manufacturing Strategies. Management Science, 40 (30), 285-304.

Morris, M. \& Allen, J. (1991). Perceived Environmental Turbulence and Its Effect on Selected Entrepreneurship, Marketing, and Organizational Characteristics in Industrial Firms. Journal of the Academy of Marketing Science, 1, 43-51.

Morrison, A. \& Roth, K. (1992). A Taxonomy of Business-level Strategies in Global Industries. Strategic Management Journal, 6, 399-418.

Mosey, S. (2005). Understanding New-to Market Product Development in SMEs. International Journal of Operations and Production Management. Vol. 25 (2): 114-130.

Mugenda, O. \& Mugenda, A. (2003). Research Methods - Quantitative and Qualitative Approaches. Nairobi, Kenya: ACTS Press.

Pearce, J. A. \& Robinson, R. B. (2007). Strategic Management: Formulation, Implementation, and Control. McGraw-Hill Companies, Inc.NY.USA. 
Porter, M. E. (1980). Competitive Strategy. New York: The Free Press.

Porter, M. E. (1990). The Competitive Advantage of Nations. Harvard Business Review, March-April, 73-93.

Republic of Kenya. (2005). Development of Micro and small Enterprises for Wealth and Employment Creation for Poverty Reduction. (Sessional Paper No.1). Nairobi: Government Printer.

Republic of Kenya. (2009). Economic Survey 2009, Nairobi: Government Printer.

Rugman, A. M. \& Verbeke, A. (2007). Liabilities of Regional Foreignness and the Use of Firm Level versus Country Level data. A response to Dunning et al (2007). Journal of International Business Studies. 38: 200-205.

Saunders, L.A. (2003). Research Methods for Business Students. $3^{\text {rd }}$ ed. Prentice Hall

Schumpeter, J. A. (1934). The Theory of Economic Development. Cambridge, Mass: Harvard University Press.

Shane, S. \& Venkataraman, S. (2000). The promise of entrepreneurship as a field of research. Academy of Management Review, 25, 217-226.

Szymanski, D., Bharadwaj, S., \& Varadarajan, P.R. (1993). Standardization versus Adaptation of International Marketing Strategy: An Empirical Investigation. Journal of Marketing, October 1-17.

Thomas, A. S. \& Mueller, S. L. (2000). A Case for Comparative Entrepreneurship. Assessing the Relevance of Culture. Journal of International Business Studies. 31(2): 287-301.

Venkataraman, N. (1989). Strategic Orientation of Business Enterprises: The Construct, Dimensionality, and Measurement. Management Science, 35, 942-962.

Wang, L. C. (2008). Entrepreneurial Orientation, Learning Orientation, and Firm Performance. Entrepreneurship Theory and Practice. Baylor University.UK.

Wanjau, K.L. (2008). The Role of Quality in Growth of Small and Medium Enterprises in Kenya. Jomo Kenyatta University of Agriculture and Technology, Unpublished PhD Thesis.

Wiklund, J. \& Shepherd, D. (2005). Entrepreneurial Orientation and Small Business Performance: A Configuration Approach. Journal of Business Venturing, 20, 71-91. 
Zahra, S.A. \& Garvis, D. M. (2000). International Corporate Entrepreneurship and Firm Performance. The Moderating Effect of International Environmental Hostility. Journal of Business Venturing. 15 (5-6): 469-492.

Zhan, J. et al. (2003). Exploring Entrepreneurial Orientation (EO) in 3 Dimensions: A New Prospective for Analysing the Value of a Company. PhD Student, Ghent University, Belgium. 